\title{
THE STONE MARTEN AND THE RED FOX CONSUMED PREDOMINANTLY FRUITS ALL YEAR ROUND: A CASE STUDY
}

\author{
Zsófia Lanszki ${ }^{1}$, Jenô J. Purger ${ }^{1}$, Renáta Bocz ${ }^{1}$, Dávid Szép ${ }^{1}$ and József Lanszki ${ }^{2}$ \\ ${ }^{1}$ Department of Ecology, University of Pécs, H-7624 Pécs, Ifjúság útja 6, Hungary \\ E-mails: lanszkizsofi@gmail.com, https://orcid.org/0000-0003-3116-4633 \\ purger@gamma.ttk.pte.hu, https://orcid.org/0000-0002-3302-6544 \\ renata.bocz@gmail.com, https://orcid.org/0000-0002-6917-6739; \\ szeep.david@gmail.com, https://orcid.org/0000-0001-9749-9159 \\ ${ }^{2}$ Carnivore Ecology Research Group, Kaposvár University, H-7400 Kaposvár, Guba S. u. 40, \\ Hungary; E-mail: lanszkij@gmail.com; https://orcid.org/0000-0002-2067-6601
}

The feeding of the stone marten (Martes foina) and the red fox (Vulpes vulpes) being flexible, easily adapt to anthropogenic food sources, utilising them effectively. Both carnivores feed on plants, thus the question arises how their food composition changes during the seasons when there is high availability of fruits in their habitat. The diet composition of the two species was investigated for one year in a 14-hectare vineyard surrounded by orchards, based on scat analysis ( $n=288$ and 110, respectively). The proportion of plant matter in the feeding of both species was strikingly high, although differing seasonally, especially fruits, mostly sour cherries, cherries, grapes and figs being present. Martens consumed plants in greater amounts $(89 \%$ vs $76 \%$ ) than foxes. Both carnivores consumed more invertebrates in spring, and more small mammals in winter, whereas frugivory was more substantial in the summer and autumn periods. Trophic niche was quite narrow in both species, with considerable degree of overlap. The revealed feeding patterns are quite novel, that of the stone marten being unique even at a European level; the prolonged high degree of frugivory indicates the perfect adaptability of the two native carnivore species.

Keywords: dietary pattern, frugivory, Martes foina, trophic niche, Vulpes vulpes.

\section{INTRODUCTION}

The strengthening of the populations of animals adaptable to the transformed anthropogenic environment, including those of carnivorous mammal species, is seen throughout Europe (ConTesse et al. 2004, Herr et al. 2009, Tóth et al. 2009, Soe et al. 2017). These include the stone marten (Martes foina; hereafter: marten) and the red fox (Vulpes vulpes; hereafter: fox). Both are common carnivore species widespread throughout much of Europe (MACDONALD 1977, Delibes 1978, Zhou et al. 2011, Soe et al. 2017). Besides factors such as few competitors, availability of shelters, and low efficiency population control (HERR et al. 2009), the fact that their populations are in a favourable status is due to the abundant availability and easy access to natural and anthropogenic food sources (Rasmussen \& Madsen 1985, Tester 1986, Lucherini \& Crema 1993, Soe et al. 2017). Their feeding is also flexible (Genovesi et al. 1996, Kidawa \& 
KowalczyK 2011, Díaz-Ruiz et al. 2013), allowing them to adapt rapidly to anthropogenic food sources, and effectively utilise them.

Both species being solitary hunters on the ground, the marten also hunts with great agility in the canopy layer. Their diet composition is relatively well known, having been studied in various kinds of regions in Europe. Being opportunistic carnivores (MacDonald 1977), their diet composition is highly varied, depending on area and seasonal food availability. The diet of martens can simultaneously include several types of food with relatively high proportions (Tester 1986, Tóth 1998, Lanszki 2003, Zhou et al. 2011, PApakosta et al. 2014). The importance of various food types in the feeding of foxes can change with geographic latitude too (Lloyd 1980, Kidawa \& KowalczyK 2011, DíazRuiz et al. 2013, Soe et al. 2017). The interspecific trophic relations of the two carnivore species are better known from Mediterranean areas (e.g. SERAFINI \& Lovari 1993, Padial et al. 2002, Santos et al. 2007), but are less studied in temperate climate zones (Goszczynski 1986, LANSZKi et al. 1999, PosŁuszny et al. 2007, Petrov et al. 2016). Only few studies have looked at the seasonal patterns and changes of feeding in these two native carnivores, at the same time and within the same area.

Our hypothesis is that sharing the same habitat, both martens and foxes feeding in an opportunistic manner, search for their food containing easily accessible fruits and common animals in the area. According to our prediction, their dietary patterns will be similar to each other, and thus differ greatly from dietary patterns recorded during diet analyses performed in natural areas or human-dominated environments.

Through the analysis of stone marten and red fox faecal samples collected through a period of one year, our aim has been to determine a) the seasonal diet composition together with its energetic background, b) the trophic niche breadth, and c) the trophic niche overlap between the two carnivore species.

\section{MATERIAL AND METHODS}

The study area is located outside the city of Pécs, in the 14-hectare vineyard (N $46.07^{\circ}$, E $18.17^{\circ}$ ) of the Research Institute for Viticulture and Winemaking, University of Pécs. Lying on the southern slopes of western Mecsek Mountains, the study area is part of the Pannonian biogeographical region of SW Hungary, located at altitudes between 180-240 m a.s.l. Wine-growing has been practised in the area since the 1750 s. The climate is continental, with considerable Mediterranean influence. In the study period the monthly average temperature is $12.6{ }^{\circ} \mathrm{C}\left(3.2{ }^{\circ} \mathrm{C}\right.$ in winter months), the total amount of precipitation is 651 $\mathrm{mm}$, the number of sunny hours is 2254 (data from the Pécs Observatory of the Hungarian Meteorological Service). The vineyard is bordered from the north by dry forests (FraxinoQuercetum), with manna ash (Fraxinus ornus) and downy oak (Quercus pubescens) being the primary tree species. In the south there is a main road, whereas on the eastern and western sides cultivated and abandoned orchards are found, with wine cellars and residential 
buildings. The presence of martens and foxes had been indicated by camera trap photos. During the study period badger (Meles meles), weasel (Mustela nivalis), domestic cat (Felis silvestris catus), wild boar (Sus scrofa), European brown hare (Lepus europaeus) and roe deer (Capreolus capreolus) were also present in the area occasionally.

The diet composition and feeding habits of stone marten and red fox were investigated by analysing scat samples collected every two weeks from the beginning of July 2015 to the end of June 2016. Samples were collected along a total of $4.28 \mathrm{~km}$ long standard route on the top of the stone walls separating vineyard plots, and along the road network running through the vineyard, and were distinguished based on odour, size and shape characteristics (MACDONALD 1980). Due to the regular human presence in the area associated with viticulture, the presence of the forest-preferring pine marten (Martes martes) in the area is considered to be only occasional even despite the proximity of forests, as suggested by experience from radio telemetry studies (ZALewski 1997, Czernik et al. 2016), meaning that the majority of the collected samples possibly originated from stone martens. No other canid species (e.g. golden jackal Canis aureus) than the red fox were directly observed or their presence inferred to from indirect signs (footprints, calls, scats), and people working in the vineyards did not observe canid species other than foxes either.

We analysed stone marten and red fox scat samples $(n=288$ and 110, respectively) by means of a standard procedure (JĘDRZEJEWSKA \& JĘDRZEJEWSKI 1998). Scats were soaked in water, then washed through a sieve $(0.5 \mathrm{~mm}$ mesh) and finally dried. All food remains were separated, all feather, bone, dentition, and hair remains were identified using microscope keys from März (1972), TEERINK (1991), Brown et al. (1993), and our own vertebrate, invertebrate and plant reference collections.

The diet composition of the carnivores was expressed in two ways: percentage relative frequency of occurrence $(\mathrm{O}$ - number of occurrences of a certain food type divided by the total number of food occurrences of all food types and then multiplied by 100), and percentage of biomass consumed (B). To estimate the fresh mass of food ingested (REYNOLDS \& Aebischer 1991), all dry food remains were weighed separately (measured at 0.01 g accuracy) and the food remain mass data were multiplied by an appropriate conversion factor (i.e. coefficient of digestibility), as summarized from literature data by JęDRZEJEwsKA and JęDRZEJEWSKI (1998) for red fox and martens.

The following ten food categories were used in the calculations related to the comparative analysis of the faecal sample composition and the trophic niche for predator species: 1 - small mammals (rodents and insectivores), 2 - European brown hare, 3 - wild carnivores, 4 - wild ungulates (carrion), 5 - wild birds (including eggs), 6 - domestic animals, 7 - reptiles and amphibians together, 8 - invertebrates, 9 - plants (fruits, seeds and other plant matter) and 10 - inorganic materials (non-food items).

General log-linear analysis (STATISTICA 10.0) was used on frequency of occurrence data to test for intraspecific differences of the two carnivore species for four seasons, and for interspecific differences. The unit of analysis was scat samples of carnivores, and the response variable was the presence or absence of the food item considered. The model was fitted using carnivore species and season as independent variables. Owing to the large number of comparisons (ten food categories), we adjusted the level of significance to 0.005 with a Bonferroni correction $(\mathrm{P}=0.05 / 10)$. Nine food categories (because there is no conversion factor for inorganic materials) were considered based on the estimated percentage of biomass consumed (arcsin transformed B values). Analysis of covariance (ANCOVA, Bonferroni post-hoc test) was applied to explore interspecific and intraspecific differences in B values, with carnivore taxa as fixed factor and season as covariate. 
To determine interspecific differences and to test whether the unusual high proportions of plant consumption and low small mammal consumption can be profitable, a simple energy content calculation was applied for both carnivores. Estimation based on seasonal percentage of biomass consumed (Fig. 1) and metabolizable energy values, which is $614.4 \mathrm{~kJ} / 100 \mathrm{~g}$ for small mammals (common vole Microtus arvalis; annual average value; GórecKi 1965), 785.14 kJ/100 g for European brown hare (МүгснA 1968), 825.0 kJ/100 g for birds (European tree sparrow Passer montanus; Мүrсha \& Pinowsкi 1970), $905.5 \mathrm{~kJ} / 100 \mathrm{~g}$ for other vertebrates (roe deer carcass; Weiner 1973), $806.4 \mathrm{~kJ} / 100 \mathrm{~g}$ for insects (beetles, Polycleis spp., Sternocera spp., imago; BukKens 1997), and $271.5 \mathrm{~kJ} / 100 \mathrm{~g}$ (in the case of marten) or $255.7 \mathrm{~kJ} / 100 \mathrm{~g}$ (in the case of fox) for plants (grape, cherry and maize, ratios, marten: 60:30:10\%, fox: 50:40:10\%; https://ndb.nal.usda.gov/ndb).

\section{Stone marten}
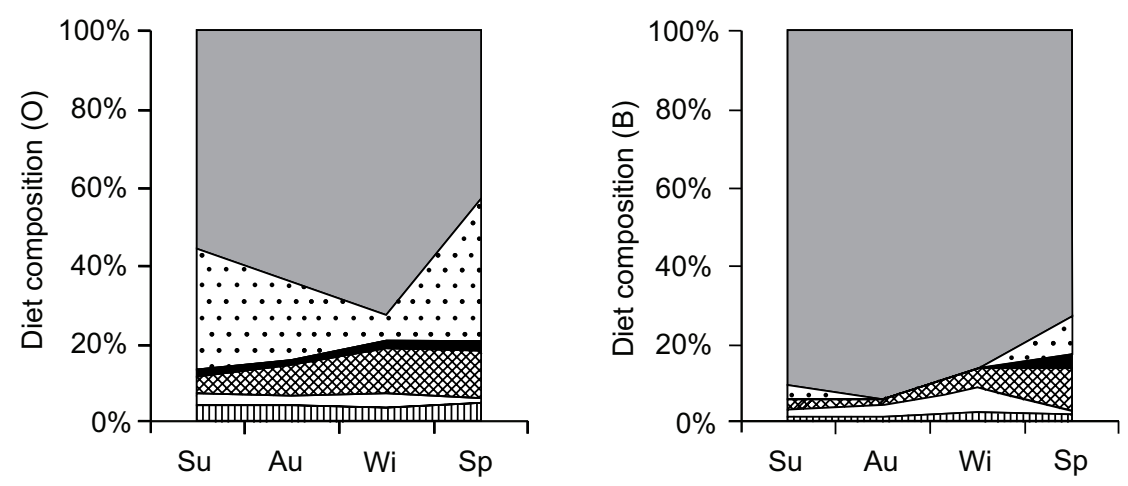

Red fox
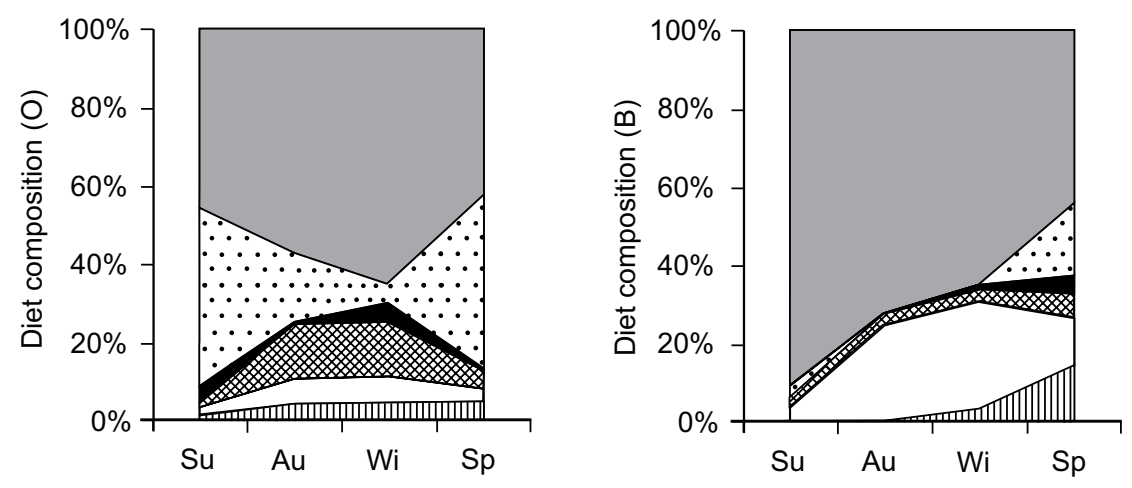

$\square$ plants $\square$ invertebrates

other vertebrates

birds $\square$ lagomorphs m small mammals

Fig. 1. Seasonal diet composition changes of stone martens (Martes foina) and red foxes (Vulpes vulpes) in a vineyard (Pécs, Hungary). Scat samples ( $\mathrm{n}=288$ and 110, respectively) collected between July 2015 and June 2016, Su - summer, Au - autumn, Wi - winter, Sp - spring, O percentage relative frequency of occurrence, $\mathrm{B}$ - percentage of biomass consumed 
Trophic niche breadth was calculated in accordance with standardized Levins index $\left(\mathrm{B}_{\mathrm{A}^{\prime}}\right.$ rating from 0 to 1$)$ according to Hurlbert, and trophic niche overlap using the Renkonen index (KREBS 1989). The estimated energy values (kJ/100 g) and standardised trophic niche breadth values (both calculated seasonally) were compared with paired samples ttest (normal data distributions). A minimum probability level of $\mathrm{P}<0.05$ was accepted in all statistical tests, except log-linear analysis.

\section{RESULTS}

In the vineyard in all seasons plants were the primary foods of the marten (annual mean, O: $62.2 \%$, B: $88.8 \%$, Appendix 1, Fig. 1) as well as of the fox (annual mean, O: $53.2 \%$, B: $76.0 \%$, Appendix 2, Fig. 1). The second and third most important food types, depending on season and the calculation method, were birds, brown hare or invertebrates. Among plants, both species consumed mainly seasonally available fruits (cherry or sour cherry Prunus sp., grape Vitis vinifera, fig Ficus carica). The main bird prey species were passerines, while the consumed invertebrates were mainly beetles. The consumption of other food types was negligible.

Based on frequency data (log-linear analysis), the difference between the feeding of the two carnivore species was not significant in any of the food types (Table 1). Among food types, significant seasonal differences were revealed only in the consumption of invertebrates, plants and inorganic material (Table 1). Both the foxes and the martens fed most frequently on invertebrates in spring, and least often in winter, and consumed plants most frequently in winter and least often in spring (Fig. 1). The consumption of

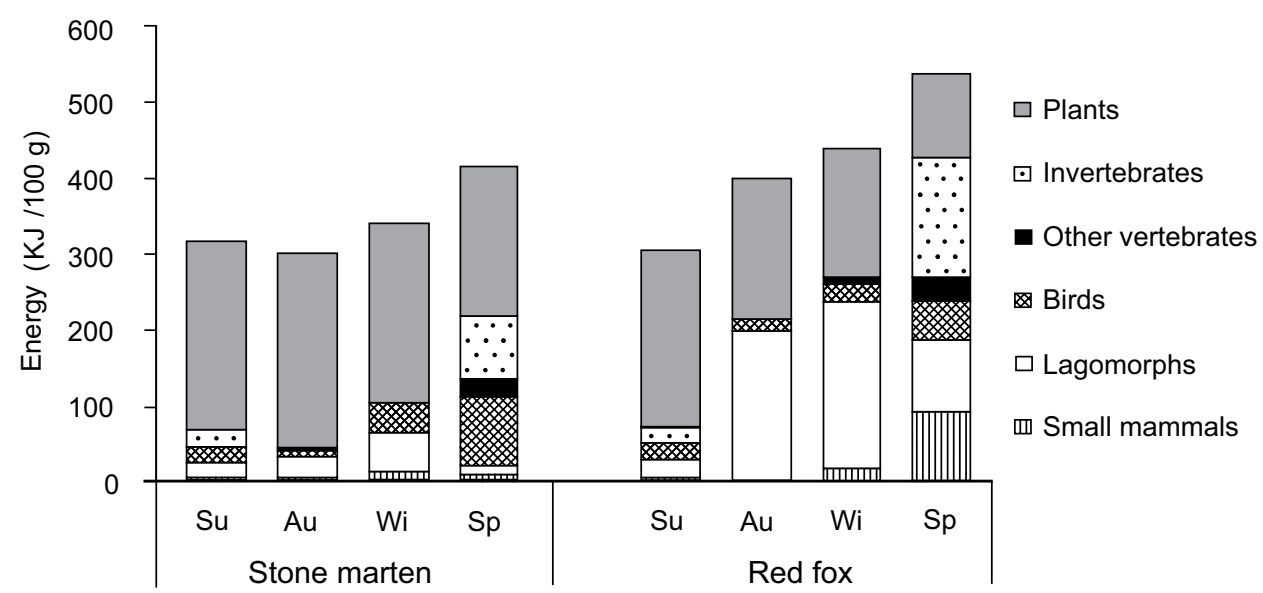

Fig. 2. Energetic values of stone marten (Martes foina) and red fox (Vulpes vulpes) diets in a vineyard (Pécs, Hungary). For abbreviations see Fig. 1 and details for calculations can be find in Material and methods 
Table 1. Results of log-linear models for the frequencies of occurrence of food types in the scats of stone martens (Martes foina) and red foxes (Vulpes vulpes) during four seasons (2015-2016) in a vineyard (Pécs, Hungary), for the effect of species, seasons, and their interaction. $\mathrm{P}$ values (with Bonferroni corrections, $\mathrm{P}<0.005$ ) in boldface are significant.

\begin{tabular}{|c|c|c|c|c|}
\hline Item & Effect & $\mathrm{df}$ & $\chi^{2}$ & $\mathrm{P}$ \\
\hline \multirow[t]{3}{*}{ Small mammals } & Species & 1 & 0.0 & 0.983 \\
\hline & Season & 3 & 1.3 & 0.728 \\
\hline & Interaction & 3 & 11.6 & 0.009 \\
\hline \multirow[t]{3}{*}{ Brown hare } & Species & 1 & 4.9 & 0.027 \\
\hline & Season & 3 & 2.4 & 0.500 \\
\hline & Interaction & 3 & 12.0 & 0.007 \\
\hline \multirow[t]{3}{*}{ Carnivores } & Species & 1 & 2.0 & 0.156 \\
\hline & Season & 3 & 1.5 & 0.683 \\
\hline & Interaction & 3 & 11.4 & 0.010 \\
\hline \multirow[t]{3}{*}{ Ungulates } & Species & 1 & 1.2 & 0.277 \\
\hline & Season & 3 & 0.4 & 0.949 \\
\hline & Interaction & 3 & 11.5 & 0.009 \\
\hline \multirow[t]{3}{*}{ Birds } & Species & 1 & 0.0 & 0.926 \\
\hline & Season & 3 & 10.3 & 0.016 \\
\hline & Interaction & 3 & 11.6 & 0.009 \\
\hline \multirow[t]{3}{*}{ Domestic animals } & Species & 1 & 0.8 & 0.375 \\
\hline & Season & 3 & 1.7 & 0.644 \\
\hline & Interaction & 3 & 11.3 & 0.010 \\
\hline \multirow[t]{3}{*}{ Reptiles and amphibians } & Species & 1 & 3.0 & 0.085 \\
\hline & Season & 3 & 2.8 & 0.420 \\
\hline & Interaction & 3 & 11.5 & 0.009 \\
\hline \multirow[t]{3}{*}{ Invertebrates } & Species & 1 & 2.1 & 0.146 \\
\hline & Season & 3 & 126.8 & $<0.0001$ \\
\hline & Interaction & 3 & 9.6 & 0.023 \\
\hline \multirow[t]{3}{*}{ Plants } & Species & 1 & 3.7 & 0.055 \\
\hline & Season & 3 & 41.3 & $<0.0001$ \\
\hline & Interaction & 3 & 9.0 & 0.029 \\
\hline \multirow[t]{3}{*}{ Inorganic materials } & Species & 1 & 1.3 & 0.256 \\
\hline & Season & 3 & 40.3 & $<0.0001$ \\
\hline & Interaction & 3 & 10.5 & 0.015 \\
\hline
\end{tabular}


inorganic materials (debris) was more frequent in spring and less frequent in summer (Appendix 3).

Based on calculated biomass composition data (ANCOVA), it was possible to indicate significant difference between the feeding of the two carnivore species only in the consumption of plant matter: martens ate higher proportions of plants than foxes $\left(\mathrm{F}_{1,5}=11.86, \mathrm{P}=0.018\right)$. Among seasons, significant difference was found only in the feeding on small mammals and plants. Both carnivores took higher proportions of small mammals in winter and smaller proportions in summer and autumn $\left(\mathrm{F}_{1,5}=7.33, \mathrm{P}=0.042\right)$, whereas plant matter was eaten in higher proportions in summer and autumn and relatively less in spring $\left(\mathrm{F}_{1,5}=20.28, \mathrm{P}=0.006\right)$. Regarding the other food types, no significant difference was revealed either between the two species $\left(\mathrm{F}_{1.5}=0.38-2.27, \mathrm{P}=\right.$ $0.192-0.564)$ or between the seasons $\left(\mathrm{F}_{1,5}=0.01-5.04, \mathrm{P}=0.075-0.940\right)$.

Estimated mean $( \pm S E$ ) energy values calculated from diets (Fig. 2) did not differ significantly between the studied carnivores (marten: $342.3 \pm 25.8 \mathrm{~kJ} / 100$ $\mathrm{g}$, fox: $420.3 \pm 48.5 \mathrm{~kJ} / 100 \mathrm{~g}$, paired samples t-test, $\mathrm{t}_{3}=2.55, \mathrm{P}=0.084$ ).

Mean $( \pm S E)$ standardised trophic niche breadth $\left(B_{A}\right)$ did not differ significantly between the species either based on frequency data $(\mathrm{O}$, marten: $0.19 \pm 0.03$, fox: $0.21 \pm 0.01$, paired samples $t$-test, $\left.t_{3}=0.67, P=0.552\right)$, or in the evaluation of calculated biomass composition data (B, marten: $0.05 \pm 0.02$, fox: $\left.0.16 \pm 0.08, \mathrm{t}_{3}=1.97, \mathrm{P}=0.144\right)$. Trophic niche overlap values were high in all seasons, using both kinds of calculation (O: $88.0 \pm 1.9 \%$, B: $79.0 \pm 7.5 \%$ ). Marten and fox diets contained 16 and 11 different vertebrate taxa, 7-7 invertebrate taxa, 12 and 11 plant taxa, respectively.

\section{DISCUSSION}

Both martens and foxes followed their opportunistic feeding strategies, utilising throughout the year food types that were readily available in the vineyard and its immediate surroundings, which supports our hypothesis. In this case study we detected seasonal influence on the diet composition of the two species only partially, depending on the calculation method, in the case of plants, small mammals, invertebrates and inorganic matter. Significant difference between the two carnivores was found only in the consumption of one of the food types i.e. plants (mostly fruits): martens consumed plant matters in higher proportions than foxes, which support our prediction that dietary patterns will be similar.

Fruits are abundantly available for the predators in the study area in summer and autumn, and the neighbouring abandoned orchards allow access to fallen fruits or unharvested grapes even during wintertime. Fleshy fruits with high levels of carbohydrate, minerals and vitamins but low pro- 
tein contents (PANDOLFi et al. 1996, JoRdANo 2000) are consumed in winter, as confirmed by numerous other studies too (e.g. Rasmussen \& Madsen 1985, Tester 1986, Tóth 1998, Bermejo \& Guitian 2000, Lanszki 2003, Bakaloudis et al. 2012, Georgiev 2013, Czernik et al. 2016, Petrov et al. 2016). Winter was mild at the time of the investigations, thus the fruits having remained in the area stayed available for quite long. The high rate of frugivory throughout the year indicates (even without telemetry investigations) that the predator species obtained their food in a relatively small area, mostly in the neighbourhood of the vineyard.

Depending on food availability, habitat type and sex, the home range of martens can range between 0.01 and $0.4 \mathrm{~km}^{2}$ (Herrmann 1994, SeIler et al. 1994, Posillico et al. 1995), while that of foxes can measure anything between 0.04 to $30 \mathrm{~km}^{2}$ (Voigt \& Macdonald 1984, Doncaster et al. 1990, Baker \& HARris 2004). Without population estimation and identification of individuals (e.g. ZALEWSKI 1999), it is impossible to find out how specific are the dietary patterns. A sample size from our systematic collecting was similar to the average of sample collected during one year from larger areas (LANsZKI 2012), in the case of both studied species. Understanding of feeding ecology of these species can also be extended by study of diet of some individuals. We could not exclude the possibility that the studied carnivores collected their food in further areas, though the items detected in their food occurred in the studied area and the near vicinity. Based on the known extent of their home range, food composition and availability, it is likely that martens and foxes consumed the majority of their food in the studied area and its immediate surroundings.

Based on findings from germination experiments with seeds from scats (Herrera 1989, Matías et al. 2010) it is assumed that carnivores play a role in dispersing fruit seeds in the neighbouring areas, and through that, in expanding their own food supply, which can be beneficial for other species too (Debussche \& Isenmann 1989, Herrera 1989, Schaumann \& Heinken 2002, Matías et al. 2010). They did not eat the fruits of invasive species, and accordingly, did not contribute to their dispersal. A telemetric tracking would provide useful insights into their seed distribution and habitat use.

The role of plant matter as food in the diet of martens and foxes in the study area was unusually important, as compared to studies in other European areas (reviewing works: Lloyd 1980, Zhou et al. 2011, LANSZKi 2012, Díaz-Ruiz et al. 2013, Раракоsta et al. 2014, Soe et al. 2017). The high degree of feeding on plant matter by martens was proved in Mediterranean forest in Portugal (B: $61.9 \%$, SANTOs et al. 2007) and in big cities in Bulgaria (O: 83.3\%, Georgiev 2013). Probably the digestive system of the stone marten requires large quantities of plant fibres (PANDolfi et al. 1996, Tóth 1998). In the case 
of foxes, high level of plants in diet was shown in a forest mixed with alpine pastures in Switzerland (O: 38,8\%, FERRARI \& WEBER 1995), and in agricultural areas with interspersed Mediterranean forests (O: 35.0\%, Cavallini \& VolPI 1996). In our study area, the percentage of plant matter in the diet of both carnivore species was much higher than in any of the former investigations, which supported our prediction.

Invertebrates had a seasonally varying but major importance in the feeding of martens and foxes in the study area, whereas the proportion of small mammals and domestic animals in their diet was smaller than in other European habitats. In foxes, the importance of feeding on wild ungulates had much smaller importance than what has been found by other European investigations (Lloyd 1980, LanszKi et al. 2007, Zhou et al. 2011, Díaz-Ruiz et al. 2013, Papáosta et al. 2014, Soe et al. 2017). The seasonality in feeding on invertebrates can be explained with the decreased activity of prey species in the cold season. Their more frequent utilisation as food was found in Mediterranean areas such as Portugal $(\mathrm{O}$, martens: $85.5 \%$, foxes: $32.8 \%$, SANTos et al. 2007) and Spain (foxes, B: 21.7\%, Fernández \& Azua 2005). Preying on small mammals was found to increase somewhat in spring when the availability of plants as main food type started to decrease, which is an interesting finding with a view to the fact that small mammal abundance is typically the highest in late summer and in autumn (Horváth \& WAGNER 2003). Such low rates of small mammals in the diet of both carnivore species as the ones revealed by our study had been reported in Portugal, in Mediterranean areas (SANTos et al. 2007). Domestic animals (pig and poultry) were very rare in our collected samples, although the consumption ratio of these are normally higher, irrespective of habitat type (e.g. Sidorovich 1997, Panek 2013). The consumption ratio of the rest of prey types (e.g. brown hare, wild carnivores, wild ungulates, wild birds, domestic animals, reptiles and amphibians) is similar to what is average in a European comparison (Lloyd 1980, Zhou et al. 2011, Díaz-Ruiz et al. 2013, Papakosta et al. 2014, Soe et al. 2017). Some of this percentage is made up by cases of predation on species such as brown hare and small birds in all seasons, while another fraction signifies scavenging, e.g. in the very few cases of roe deer evidence. In some cases both predation and scavenging are equally possible, e.g. in the case of mustelids and pheasants. Contrary to our prediction, the consumption of the fast-moving lizards was found to be rare, despite the frequent occurrence of lizards in the area (PURGER et al. 2017). Studies in areas further to the south indicated a more frequent (3.7-13.0\%) consumption of reptiles (mostly lizards) by martens (e.g. Delibes 1978, Romanowski \& Lesinski 1991, Lucherini \& Crema 1993, Bakaloudis et al. 2012). The consumption of inorganic material, possibly from domestic waste, became more frequent in winter and spring when most of the natural 
food sources have limited availability (e.g. RASmussen \& MAdsen 1985, Tester 1986, Doncaster et al. 1990, Ferrari \& Weber 1995, Lanszki 2003, Bakaloudis et al. 2012, Papakosta et al. 2014).

Due to the dominance of low-energy plant food, the energy content of the diet of marten and fox in our case study was lower than that of the average diet composition (marten: $560.5 \mathrm{~kJ} / 100 \mathrm{~g}$, fox: $623.2 \mathrm{~kJ} / 100 \mathrm{~g}$ ) in the southwestern part of Hungary (LANSZKi 2012). Closest to these averages were the calculated energy content values of food consumed during spring in the vineyard in the study area. Spring is the time of cubbing and early parental care period (Lloyd 1980), therefore the highest protein requirement occurs at this time. Although the energy content of summer and autumn foods was relatively low, however, due to high abundance of fleshy fruits (e.g. BaKaloudis et al. 2012, Petrov et al. 2016), predators could satisfy their energy needs. Dietary patterns for both species showed greater similarity to the Mediterranean area of Europe and deviated from the dietary patterns found in temperate areas (Lloyd 1980, Zhou et al. 2011, Lanszki 2012, Díaz-Ruiz et al. 2013, Раракоsta et al. 2014, Soe et al. 2017).

While both the martens and the foxes consumed from a variety of food types, their trophic niche was relatively narrow throughout the year due to frugivory, and also showed a high degree of trophic niche overlap. Despite this, individuals belonging to both species were continuously found to be present in the same area. Our results from the analysis of the feeding of sympatric martens and foxes supported findings from earlier studies (70-90\% overlap; Goszczynski 1986, Serafini \& Lovari 1993, Lanszki et al. 1999, Baltrunaité 2002, Padial et al. 2002, PosŁuszny et al. 2007; except Santos et al. 2007), with the reservation that the food types with primary importance were different in the various study areas. Carnivores can co-exist under a considerable degree of overlap in their diet (e.g. JedrZejewsKa \& Jedrzejewski 1998, RemonTi et al. 2012, Petrov et al. 2016), provided that food is abundantly available (KREBS 1989), the resources are partitioned in time, by partial spatial separation (Petrov et al. 2016), by the difference in hunting strategies (Rosenzweig 1966, DayAn \& Simberloff 1994), or one of the species has a more variable diet (Gittleman 1989). As signified by the dietary patterns, plant matter in the orchards around the studied vineyard area continued to have virtually unlimited availability even in winter.

In conclusion, it is established that the recorded feeding patterns of martens and foxes, namely the prolonged high degree of frugivory in a vineyard, are new findings on a European scale, and suggest that these predator species are capable of surviving on high proportions of fruit in their diet throughout the year. Their co-existence despite a high level of trophic niche overlap between them is another evidence for their excellent adaptability. 
Acknowledgements - We are thankful to the management and staff members of the Research Institute for Viticulture and Winemaking, University of Pécs, for their unlimited support in our work and to anonymous reviewers for their advice and comments. This study was supported by the PhD School of Biology and Sport Biology, University of Pécs and the EFOP-3.6.1-16-2016-00007 project.

\section{REFERENCES}

Bakaloudis, D. E., Vlachos, C. G., Papakosta, M. A., Bontzorlos, V. A. \& Chatzinikos, E. N. (2012): Diet composition and feeding strategies of the stone marten (Martes foina) in a typical Mediterranean ecosystem. - The Scientific World Journal 2012: ID163920. https://doi.org/10.1100/2012/163920

Baker, P. J. \& Harris, S. (2004): Red foxes. Pp. 207-216. In: Macdonald, D. W. \& SilleroZubiri, C. (eds): The behavioural ecology of red foxes in urban Bristol. Biology and conservation of wild canids. - Oxford University Press, Oxford.

Baltrunaité, L. (2002): Diet composition of the red fox (Vulpes vulpes L.), pine marten (Martes martes L.) and raccoon dog (Nyctereutes procyonoides Gray) in clay plain landscape, Lithuania. - Acta Zoologica Lituanica 12: 362-368. https://doi.org/10.1080/1 3921657.2002 .10512525

Bermejo, T. \& Guitian, J. (2000): Fruit consumption by foxes and martens in NW Spain in autumn: A comparison of natural and agricultural areas. - Folia Zoologica 49: 89-92.

Brown, R., Ferguson, J., Lawrence, M. \& Lees, D. (1993): Federn, Spuren und Zeichen der Vögel Europas: Ein Feldführer. - Aula-Verlag, Wiesbaden, 232 pp.

Bukкens, S. G. (1997): The nutritional value of edible insects. - Ecology of Food and Nutrition 36: 287-319. https://doi.org/10.1080/03670244.1997.9991521

Cavallini, P. \& Volpi, T. (1996): Variation in the diet of the red fox in a Mediterranean area. - Revue d'Ecologie - La Terre et la Vie 51: 173-189.

Contesse, P., Hegglin, D., Gloor, S., Bontadina, F. \& Deplazes, P. (2004): The diet of urban foxes (Vulpes vulpes) and the availability of anthropogenic food in the city of Zurich, Switzerland. - Mammalian Biology 69: 81-95. https://doi.org/10.1078/16165047-00123

Czernik, M., KowalczyK, R. \& Zalewski, A. (2016): Spatio-temporal variation of predator diet in a rural habitat: stone martens in the villages of Bialowieza forest. - Mammal Research 61: 187-196. https://doi.org/10.1007/s13364-016-0273-1

DAYAN, T. \& SimberlofF, D. (1994): Character displacement, sexual dimorphism, and morphological variation among British and Irish mustelids. - Ecology 75: 1063-1073. https://doi.org/10.2307/1939430

Debussche, M. \& Isenmann, P. (1989): Fleshy fruit characters and the choices of bird and mammal seed dispersers in a Mediterranean region. - Oikos 56: 327-338.

Delibes, M. (1978): Feeding habits of the stone marten, Martes foina (Erxleben, 1777), in northern Burgos, Spain. - Zeitschrift für Säugetierkunde 43: 282-288.

Díaz-Ruiz, F., Delibes-Mateos, M., García-Moreno, J. L., López-Martín, J. M., Ferreira, C. \& Ferreras, P. (2013): Biogeographical patterns in the diet of an opportunistic predator: the red fox Vulpes vulpes in the Iberian Peninsula. - Mammal Review 43: 59-70. https://doi.org/10.1111/j.1365-2907.2011.00206.x 
Doncaster, C. P., Dickman, C. R. \& Macdonald, D. W. (1990): Feeding ecology of red foxes (Vulpes vulpes) in the city of Oxford, England. - Journal of Mammalogy 71: 188-194. https://doi.org/10.2307/1382166

FernÁNDEz, J. M. \& AzuA, N. R. (2005): Dieta y solapamiento trófico primaveral del zorro rojo Vulpes vulpes y de Martes sp. en simpatría en Álava (Norte de España). Ecología 19: 167-182.

Ferrari, N. \& Weber, J. M. (1995): Influence of the abundance of food resources on the feeding habits of the red fox, Vulpes vulpes, in western Switzerland. - Journal of Zoology 236: 117-129. https://doi.org/10.1111/j.1469-7998.1995.tb01788.x

Genovesi, P., Secchi, M. \& Boitani, L. (1996): Diet of stone martens: an example of ecological flexibility. - Journal of Zoology 238: 545-555. https://doi.org/10.1111/j.1469-7998.1996. tb05412.x

Georgiev, D. (2013): Diet of the stone marten (Martes foina Erxl.) in two large cities of the Upper Thracian Lowland, South Bulgaria. - ZooNotes 42: 1-4.

Gittleman, J. L. (1989): Carnivore group living: comparative trends. Pp. 183-207. In: Gittleman, J. L. (ed.): Carnivore behavior, ecology, and evolution. - Cornell University Press, New York.

GóreCKI, A. (1965): Energy values of body in small mammals. - Acta Theriologica 10: 333-352.

Goszczynski, J. (1986): Diet of foxes and martens in central Poland. - Acta Theriologica 31: 491-506.

Herr, J., Schley, L. \& Roper, T. J. (2009): Stone martens (Martes foina) and cars: investigation of a common human-wildlife conflict. - European Journal of Wildlife Research 55: 471-477. https://doi.org/10.1007/s10344-009-0263-6

Herrera, C. M. (1989): Frugivory and seed dispersal by carnivorous mammals, and associated fruit characteristics, in undisturbed Mediterranean habitats. - Oikos 55: 250-262. https://doi.org/10.2307/3565429

Herrmann, M. (1994): Habitat use and spatial organization by the stone marten. Pp. 122136. In: Buskirk, S. W., Harestad, A. S., Raphael, M. G. \& Powell, R. A. (eds): Martens, sables and fishers biology and conservation. - Cornell University Press, Ithaca.

Horváth, G. \& WaGner, Z. (2003): Effect of densities of two coexistent small mammal populations on the survival of Apodemus flavicollis in a forest habitat. - Tiscia 34: 41-46.

https://ndb.nal.usda.gov/ndb (2018): Food Composition Databases. United States Department of Agriculture, Agricultural Research Service v.3.9.5 2018-08-24

JęDrZejewskA, B. \& JęDrZejewski, W. (1998): Predation in vertebrate communities. The Bialowieza Primeval Forest as a case study. - Springer-Verlag, Berlin, $450 \mathrm{pp}$.

Jordano, P. (2000): Fruits and frugivory. Pp. 125-166. In: Fenner, M. (ed.): Seeds: the ecology of regeneration in plant communities, 2nd edition. - CABI Publ, Wallingford, UK.

KidawA, D. \& KowALCZYK, R. (2011): The effects of sex, age, season and habitat on diet of the red fox Vulpes vulpes in northeastern Poland. - Acta Theriologica 56: 209-218. https://doi.org/10.1007/s13364-011-0031-3

Krebs, C. J. (1989): Ecological methodology. - Harper Collins Publishers, New York, 654 pp.

LANSZKI, J. (2003): Feeding habits of stone martens in a Hungarian village and its surroundings. - Folia Zoologica 52: 367-377.

LANSZKI, J. (2012): Trophic relations of carnivores living in Hungary. - Directorate of Somogy County Museums, Kaposvár, 310 pp.

Lanszki, J., Körmendi, S., Hancz, Cs. \& Zalewski, A. (1999): Feeding habits and trophic niche overlap in a carnivora community of Hungary. - Acta Theriologica 44: 429-442. 
LanszKi, J., Zalewski, A. \& Horváth, G. (2007): Comparison of red fox Vulpes vulpes and pine marten Martes martes food habits in a deciduous forest in Hungary. - Wildlife Biology 13: 258-271. https://doi.org/10.2981/0909-6396(2007)13[258:CORFVV]2.0.CO;2

Lloyd, H. G. (1980): The red fox. - Batsford Ltd., London, 320 pp.

Lucherini, M. \& Crema, G. (1993): Diet of urban stone martens in Italy. - Mammalia 57: 274-277.

MacDonald, D. W. (1977): On food preference in the red fox. - Mammal Review 7: 7-23. https://doi.org/10.1111/j.1365-2907.1977.tb00359.x

MacDonald, D. W. (1980): Patterns of scent marking with urine and faeces amongst carnivore communities. - Symposium Zoological Society London 45: 107-139.

März, R. (1972): Gewöll- und Rupfungskunde. - Akademie Verlag, Berlin, 398 pp.

Matías, L., Zamora, R., Mendoza, I. \& Hódar, J. A. (2010): Seed dispersal patterns by large frugivorous mammals in a degraded mosaic landscape. - Restoration Ecology 18: 619-627. https://doi.org/10.1111/j.1526-100X.2008.00475.x

Myrcha, A. \& Pinowski, J. (1970): Weights, body composition, and caloric value of postjuvenal molting European Tree Sparrows (Passer montanus). - The Condor 72: 175-181.

Myrcha, A. (1968): Caloric value and chemical composition of the body of the European hare. - Acta Theriologica 13: 65-71.

Padial, J. M., Ávila, E. \& Gil-Sanchez, J. M. (2002): Feeding habits and overlap among red fox (Vulpes vulpes) and stone marten (Martes foina) in two Mediterranean mountain habitats. - Zeitschrift für Säugetierkunde 67: 137-146.

Pandolfi, M., Marinis de, A. M. \& Petrov, I. (1996): Fruits as a winter feeding resource in the diet of stone marten (Martes foina) in east-central Italy. - Zeitschrift für Säugetierkunde 61: 215-220.

PANeK, M. (2013): Long-term changes in the feeding pattern of red foxes Vulpes vulpes and their predation on brown hares Lepus europaeus in western Poland. - European Journal of Wildlife Research 59: 581-586. https://doi.org/10.1007/s10344-013-0709-8

Papakosta, M., Kitikidou, K., Bakaloudis, D. \& Vlachos, C. (2014): Dietary variation of the stone marten (Martes foina): A meta-analysis approach. - Wildlife Biology in Practice 10: 85-101. https://doi.org/10.2461/wbp.2014.10.11

Petrov, P. R., Popova, E. D. \& Zlatanova, D. P. (2016): Niche partitioning among the red fox Vulpes vulpes (L.), stone marten Martes foina (Erxleben) and pine marten Martes martes (L.) in two mountains in Bulgaria. - Acta Zoologica Bulgarica 68: 375-390.

Posillico, M., Serafini, P. \& Lovari, S. (1995): Activity patterns of the stone marten Martes foina Erxleben, 1777, in relation to some environmental factors. - Hystrix 7: 79-97.

PosŁuszny, M., Pilot, M., Goszczyński, J. \& Gralak, B. (2007): Diet of sympatric pine marten (Martes foina) and stone marten (Martes foina) identified by genotyping of DNA from faeces. - Annales Zoologici Fennici 44: 269-284.

Purger, J. J., LANSzKI, Zs., SzÉP, D. \& Bocz, R. (2017): Predation of common wall lizards: experiences from a study using scentless plasticine lizards. - Acta Herpetologica 12: 181-186. http://dx.doi.org/10.13128/Acta_Herpetol-20339

Rasmussen, A. M. \& Madsen, A. B. (1985): The diet of the stone marten Martes foina in Denmark. - Natura Jutlandica 21: 141-144.

Remonti, L., Balestrieri, A., Ruiz-González, A., Gómez-Moliner, B. J., Capelli, E. \& PriGIONI, C. (2012): Intraguild dietary overlap and its possible relationship to the coexistence of mesocarnivores in intensive agricultural habitats. - Population Ecology 54: 521-532. https://doi.org/10.1007/s10144-012-0337-2 
Reynolds, J. C. \& Aebischer, N. J. (1991): Comparison and quantification of carnivore diet by faecal analysis: a critique, with recommendations, based on a study of the fox Vulpes vulpes. - Mammal Review 21: 97-122. https://doi.org/10.1111/j.1365-2907.1991. tb00113.x

Romanowski, J. \& Lesinski, G. (1991): A note on the diet of stone marten in south-eastern Romania. - Acta Theriologica 36: 201-204.

Rosenzweig, M. L. (1966): Community structure in sympatric Carnivora. - Journal of Mammalogy 47: 602-612. https://doi.org/10.2307/1377891

Santos, M. J., Pinto, B. M. \&, Santos-Reis, M. (2007): Trophic niche partitioning between two native and two exotic carnivores in SW Portugal. - Web Ecology 7:53-62. https:// doi.org/10.5194/we-7-53-2007

Schaumann, F. \& Heinken, T. (2002): Endozoochorous seed dispersal by martens (Martes foina, M. martes) in two woodland habitats. - Flora-Morphology, Distribution, Functional Ecology of Plants 197: 370-378.

Seiler, A., Krüger, H. H. \& Festetics, A. (1994): Reaction of a male stone marten (Martes foina Erxleben, 1777) to foreign faeces within its territory: a field experiment. Zeitschrift für Säugetierkunde 59: 58-60.

Serafini, P. \& Lovari, S. (1993): Food habits and trophic niche overlap of the red fox and the stone marten in a Mediterranean rural area. - Acta Theriologica 38: 233-244.

Sidorovich, V. (1997): Mustelids in Belarus. - Zolotoy uley Publisher, Minsk, 263 pp.

Soe, E., Davison, J., Süld, K., Valdmann, H., Laurimaa, L. \& Saarma, U. (2017): Europewide biogeographical patterns in the diet of an ecologically and epidemiologically important mesopredator, the red fox Vulpes vulpes: a quantitative review. - Mammal Review 47: 198-211. https://doi.org/10.1111/mam.12092

TeERInK, B. J. (1991): Hair of West European mammals. - Cambridge University Press, Cambridge, $224 \mathrm{pp}$.

Tester, U. (1986): Vergleichende Nahrungsuntersuchung beim Steinmarder Martes foina (Erxleben, 1777) in großstädtischem und ländlichem Habitat. - Säugetierkundliche Mitteilungen 33: 37-52.

То́тн, А. M. (1998): Data to the diet of the urban stone marten (Martes foina Erxleben) in Budapest. - Opuscula Zoologica Budapest 31: 113-118.

Tóth, M., BÁRÁNY, A. \& KIs, R. (2009): An evaluation of stone marten (Martes foina) records in the city of Budapest, Hungary. - Acta Zoologica Academiae Scientiarum Hungaricae 55: 199-209.

Voigt, D. R. \& Macdonald, D. W. (1984): Variation in the spatial and social behaviour of the red fox, Vulpes vulpes. - Annales Zoologici Fennici 171: 261-265.

WeINER, J. (1973): Dressing percentage, gross body composition and caloric value of the roe-deer. - Acta Theriologica 18: 209-222.

ZALEWSKI, A. (1997): Factors affecting selection of resting site type by pine marten in primeval deciduous forests (Białowieża National Park, Poland). - Acta Theriologica 42: 271-288.

Zalewski, A. (1999): Identifying sex and individuals of pine marten using snow track measurements. - Wildlife Society Bulletin 27: 28-31.

Zhou, Y. B., Newman, C., Xu, W. T., Buesching, C. D., Zalewski, A., Kaneko, Y., Macdonald, D. W. \&, XIE, Z. Q. (2011): Biogeographical variation in the diet of Holarctic martens (genus Martes, Mammalia: Carnivora: Mustelidae): adaptive foraging in generalists. - Journal of Biogeography 38:137-147. https://doi.org/10.1111/j.1365-2699.2010.02396.x

Received February 24, 2018, accepted December 30, 2018, published March 18, 2019 
Appendix 1. Seasonal and annual relative frequency of occurrence and biomass percentage of food items in scats of stone martens (Martes foina) in a vineyard (Pécs, Hungary). Scat samples collected between July 2015 and June 2016, O - percentage relative frequency of occurrence, B - percentage of consumed biomass, +- biomass under $0.05 \%$, $B_{A}-$ standardized trophic niche breadth value.

\begin{tabular}{|c|c|c|c|c|c|c|c|c|c|c|}
\hline \multirow{2}{*}{ Food items } & \multicolumn{2}{|c|}{ Summer } & \multicolumn{2}{|c|}{ Autumn } & \multicolumn{2}{|c|}{ Winter } & \multicolumn{2}{|c|}{ Spring } & \multicolumn{2}{|c|}{ Annual } \\
\hline & $\mathrm{O}$ & B & $\mathrm{O}$ & B & $\mathrm{O}$ & B & $\mathrm{O}$ & B & $\mathrm{O}$ & $\mathrm{B}$ \\
\hline Microtus sp. & 0.7 & 0.2 & 2.5 & 0.8 & & & 1.0 & 0.3 & 0.9 & 0.3 \\
\hline Myodes glareolus & 0.7 & 0.2 & & & & & & & 0.2 & + \\
\hline Apodemus sp. & 2.1 & + & 1.9 & + & 3.4 & 1.4 & 2.0 & 0.2 & 2.5 & 0.6 \\
\hline Rattus norvegicus & 0.7 & + & & & 0.4 & 0.6 & 2.0 & 1.1 & 0.6 & 0.4 \\
\hline Lepus europaeus & 2.8 & 2.8 & 1.9 & 3.3 & 2.6 & 5.1 & 1.0 & 1.2 & 2.2 & 3.7 \\
\hline Mustelidae, indet. & & & & & 0.4 & 1.2 & & & 0.2 & 0.5 \\
\hline Capreolus capreolus & 0.7 & 0.1 & & & & & & & 0.2 & + \\
\hline Domestic pig & & & & & & & 1.0 & 2.4 & 0.2 & 0.2 \\
\hline Poultry & & & & & 1.3 & 0.1 & 1.0 & 0.2 & 0.6 & + \\
\hline Fringillidae & & & & & 0.4 & 0.3 & & & 0.2 & 0.1 \\
\hline Passeridae & 0.7 & + & & & & & & & 0.2 & + \\
\hline Turdidae & 0.7 & + & 1.9 & 0.3 & & & & & 0.6 & 0.1 \\
\hline Passeriformes spp. & 1.4 & 1.7 & 3.1 & 0.3 & 5.5 & 0.9 & 9.1 & 10.8 & 4.5 & 1.8 \\
\hline Phasianus colchicus & & & 0.6 & 0.2 & & & & & 0.2 & 0.1 \\
\hline Aves, medium-sized & 0.7 & + & & & & & & & 0.2 & + \\
\hline Aves, indet. & 1.4 & 0.3 & 2.5 & 0.4 & 6.4 & 3.6 & 3.0 & 0.2 & 3.7 & 1.6 \\
\hline Aves, egg & & & 0.6 & + & & & & & 0.2 & + \\
\hline Sauria & 0.7 & + & 0.6 & + & & & & & 0.3 & + \\
\hline Oryctes nasicornis & 0.7 & 0.3 & & & & & & & 0.2 & 0.1 \\
\hline Lucanus cervus & 2.8 & 0.4 & & & & & 2.0 & 0.3 & 0.9 & 0.1 \\
\hline Cetoniinae & 0.7 & 0.1 & 1.9 & + & & & 4.0 & 1.5 & 1.2 & 0.2 \\
\hline Melolonthidae & & & & & & & 3.0 & 2.2 & 0.5 & 0.2 \\
\hline Carabidae & 2.8 & 0.1 & & & 0.4 & + & 6.1 & 0.7 & 1.7 & 0.1 \\
\hline Coleoptera & 20.7 & 2.3 & 3.7 & + & 3.0 & + & 15.2 & 5.4 & 9.0 & 1.1 \\
\hline Orthoptera & 1.4 & + & 2.5 & + & 0.4 & + & 1.0 & + & 1.2 & + \\
\hline Vespidae & & & 1.9 & + & & & & & 0.5 & + \\
\hline Insecta & 2.1 & + & 9.9 & 0.1 & 0.9 & + & 5.1 & 0.2 & 4.1 & + \\
\hline Insecta, larvae & & & 0.6 & + & 2.1 & + & & & 0.9 & + \\
\hline Vitis vinifera & 12.4 & 10.9 & 36.4 & 73.1 & 41.3 & 75.1 & 4.0 & 6.0 & 27.8 & 52.0 \\
\hline Rubus sp. & 2.1 & 5.0 & & & & & 1.0 & + & 0.6 & 1.3 \\
\hline
\end{tabular}


Appendix 1 (continued)

\begin{tabular}{lcccccccccc}
\hline \multirow{2}{*}{ Food items } & \multicolumn{3}{c}{ Summer } & \multicolumn{2}{c}{ Autumn } & \multicolumn{2}{c}{ Winter } & \multicolumn{2}{c}{ Spring } & \multicolumn{2}{c}{ Annual } \\
\cline { 2 - 11 } & $\mathrm{O}$ & $\mathrm{B}$ & $\mathrm{O}$ & $\mathrm{B}$ & $\mathrm{O}$ & $\mathrm{B}$ & $\mathrm{O}$ & $\mathrm{B}$ & $\mathrm{O}$ & $\mathrm{B}$ \\
\hline Prunus avium & 1.4 & 6.2 & & & & & 14.1 & 58.5 & 2.5 & 6.8 \\
Prunus cerasus & 20.0 & 54.4 & & & & & & & 4.5 & 13.9 \\
Prunus domestica & 2.8 & 3.9 & 0.6 & 0.6 & 0.4 & 1.1 & & & 0.9 & 1.6 \\
Cornus mas & 0.7 & 0.9 & 0.6 & 1.4 & & & & & 0.3 & 0.6 \\
Malus/Pyrus sp. & 0.7 & 0.4 & 2.5 & 4.3 & 0.4 & 0.1 & & & 0.9 & 1.3 \\
Ficus carica & 3.4 & 2.0 & 6.8 & 4.4 & & & & & 2.5 & 1.7 \\
Fleshy fruits, indet. & 1.4 & 0.4 & 1.2 & 0.9 & 0.9 & 0.3 & 2.0 & 4.3 & 1.2 & 0.8 \\
Seeds & 8.3 & 6.6 & 9.3 & 6.6 & 12.3 & 4.1 & 12.1 & 0.7 & 10.6 & 5.1 \\
Poaceae & 2.1 & 0.2 & & & 1.7 & 0.3 & 1.0 & 0.2 & 1.2 & 0.2 \\
Plant debris & 0.7 & 0.6 & 6.8 & 3.3 & 15.7 & 5.7 & 9.1 & 3.6 & 9.0 & 3.6 \\
\hline Number of scats analysed & 56 & & 70 & & 118 & & 44 & & 288 & \\
Number of items & 145 & & 162 & & 235 & & 99 & & 641 & \\
$B_{A}$ & 0.20 & 0.03 & 0.17 & 0.02 & 0.12 & 0.05 & 0.28 & 0.11 & 0.19 & 0.05 \\
\hline
\end{tabular}

Appendix 2. Seasonal and annual relative frequency of occurrence and biomass percentage of food items in scats of red foxes (Vulpes vulpes) in a vineyard (Pécs, Hungary). For abbreviations see Appendix 1.

\begin{tabular}{|c|c|c|c|c|c|c|c|c|c|c|}
\hline \multirow{2}{*}{ Food items } & \multicolumn{2}{|c|}{ Summer } & \multicolumn{2}{|c|}{ Autumn } & \multicolumn{2}{|c|}{ Winter } & \multicolumn{2}{|c|}{ Spring } & \multicolumn{2}{|c|}{ Annual } \\
\hline & $\mathrm{O}$ & B & $\mathrm{O}$ & B & $\mathrm{O}$ & B & $\mathrm{O}$ & B & $\mathrm{O}$ & B \\
\hline Microtus sp. & & & & & 1.0 & 0.4 & 3.4 & 13.5 & 1.1 & 1.7 \\
\hline Apodemus sp. & 1.2 & 0.3 & 3.6 & + & 3.1 & 2.4 & 1.7 & 0.9 & 2.3 & 1.0 \\
\hline Lepus europaeus & 2.5 & 3.2 & 7.1 & 24.9 & 7.2 & 28.1 & 1.7 & 12.3 & 4.5 & 13.7 \\
\hline Mustelidae, indet. & & & & & & & 1.7 & 3.8 & 0.4 & 0.4 \\
\hline Capreolus capreolus & & & & & 1.0 & 0.4 & & & 0.4 & 0.1 \\
\hline Poultry & 1.2 & + & & & 2.1 & 0.5 & & & 1.1 & 0.2 \\
\hline Fringillidae & & & 3.6 & 0.3 & 2.1 & 0.9 & & & 1.1 & 0.3 \\
\hline Passeridae & & & & & 3.1 & 1.0 & & & 1.1 & 0.3 \\
\hline Passeriformes spp. & 1.2 & 2.2 & 3.6 & 0.1 & 4.1 & 0.2 & 3.4 & 5.9 & 3.0 & 1.9 \\
\hline Aves, indet. & & & 7.1 & 1.9 & 4.1 & 0.6 & 1.7 & 0.3 & 2.6 & 0.4 \\
\hline Aves, egg & & & & & 1.0 & + & & & 0.4 & + \\
\hline Sauria & & & & & 1.0 & + & & & 0.4 & + \\
\hline Anura & 2.5 & 0.1 & & & & & & & 0.8 & 0.1 \\
\hline Lucanus cervus & 4.9 & 0.1 & & & & & 3.4 & 0.5 & 2.3 & 0.1 \\
\hline
\end{tabular}


Appendix 2 (continued)

\begin{tabular}{|c|c|c|c|c|c|c|c|c|c|c|}
\hline \multirow{2}{*}{ Food items } & \multicolumn{2}{|c|}{ Summer } & \multicolumn{2}{|c|}{ Autumn } & \multicolumn{2}{|c|}{ Winter } & \multicolumn{2}{|c|}{ Spring } & \multicolumn{2}{|c|}{ Annual } \\
\hline & $\mathrm{O}$ & B & $\mathrm{O}$ & $\mathrm{B}$ & $\mathrm{O}$ & B & $\mathrm{O}$ & B & $\mathrm{O}$ & B \\
\hline Cetoniinae & 11.1 & 0.3 & & & & & 15.3 & 11.4 & 6.8 & 1.5 \\
\hline Melolonthidae & 1.2 & + & & & & & 10.2 & 5.3 & 2.6 & 0.6 \\
\hline Carabidae & 4.9 & 0.2 & & & 1.0 & 0.1 & 5.1 & 0.9 & 3.0 & 0.2 \\
\hline Coleoptera & 21.0 & 2.4 & & & 2.1 & + & 3.4 & 1.2 & 7.9 & 1.3 \\
\hline Gryllotalpa gryllotalpa & 1.2 & 0.1 & & & & & & & 0.4 & 0.1 \\
\hline Orthoptera & & & 3.6 & + & & & 1.7 & + & 0.8 & + \\
\hline Insecta & & & 14.3 & + & 2.1 & + & 5.1 & + & 3.4 & + \\
\hline Gastropoda & 1.2 & + & & & & & & & 0.4 & + \\
\hline Vitis vinifera & 3.7 & 3.3 & 42.9 & 67.1 & 40.2 & 61.6 & & & 20.4 & 26.1 \\
\hline Rubus sp. & 1.2 & 2.5 & & & & & 3.4 & + & 1.1 & 1.2 \\
\hline Prunus sp. & 21.0 & 60.0 & & & & & 6.8 & 17.1 & 7.9 & 31.5 \\
\hline Prunus domestica & 1.2 & 0.3 & & & & & & & 0.4 & 0.1 \\
\hline Ficus carica & 2.5 & 1.9 & 3.6 & 0.5 & 1.0 & 0.1 & & & 1.5 & 1.0 \\
\hline Fleshy fruits, indet. & 3.7 & 11.2 & 7.1 & 5.0 & 3.1 & + & 5.1 & 0.1 & 4.2 & 6.0 \\
\hline Triticum aestivum & & & & & 1.0 & + & & & 0.4 & + \\
\hline Zea mays & 2.5 & 10.5 & & & & & 3.4 & 20.7 & 1.5 & 7.6 \\
\hline Seeds, indet. & 4.9 & + & & & 4.1 & 0.1 & 11.9 & 0.2 & 5.7 & 0.1 \\
\hline Poaceae & 1.2 & + & & & 1.0 & 0.1 & 5.1 & 1.8 & 1.9 & 0.2 \\
\hline Plant debris & 3.7 & 1.3 & 3.6 & 0.3 & 14.4 & 3.3 & 6.8 & 4.0 & 8.3 & 2.1 \\
\hline Number of scats analysed & 29 & & 12 & & 44 & & 25 & & 110 & \\
\hline Number of items & 81 & & 28 & & 97 & & 59 & & 265 & \\
\hline $\mathrm{B}_{\mathrm{A}}$ & 0.20 & 0.03 & 0.23 & 0.10 & 0.17 & 0.14 & 0.23 & 0.38 & 0.21 & 0.16 \\
\hline
\end{tabular}


Appendix 3. Inorganic materials in the scats of stone martens (Martes foina) and red foxes (Vulpes vulpes) in a vineyard (Pécs, Hungary). Number of cases, SM - stone marten, RF - red fox.

\begin{tabular}{|c|c|c|c|c|c|c|c|c|}
\hline \multirow{2}{*}{ Non-food items } & \multicolumn{2}{|c|}{ Summer } & \multicolumn{2}{|c|}{ Autumn } & \multicolumn{2}{|c|}{ Winter } & \multicolumn{2}{|c|}{ Spring } \\
\hline & SM & RF & SM & $\mathrm{RF}$ & SM & $\mathrm{RF}$ & SM & $\mathrm{RF}$ \\
\hline Aluminium foil & & & 1 & 2 & & & & \\
\hline Pieces of nylon & 2 & & 2 & & 3 & 3 & 1 & 1 \\
\hline Rubber & & & 1 & & 1 & & & \\
\hline Polystyrene & & & & & 2 & & & \\
\hline Fabric & & & & & & & & 1 \\
\hline String & & & & 1 & 1 & 1 & & \\
\hline Pebbles & & & & & & 4 & & 9 \\
\hline Wood shavings & 1 & & & & 14 & 3 & 11 & 6 \\
\hline
\end{tabular}

